\title{
Crop residues activity against the free-living stages of small ruminant nematodes
}

Atividade de resíduos de culturas contra os estágios de vida livre de nematoides de pequenos ruminantes

Hévila Oliveira Salles* (1); Ana Carolina Linhares Braga²; Danisvânia Ripardo Nascimento³;

Mayara Stephanny Melo Prado ${ }^{3}$; Henrique Antunes de Souza ${ }^{4}$; Eduardo Luiz de Oliveira ${ }^{1}$; Luiz da Silva Vieira ${ }^{1}$; Antônio Cézar Rocha Cavalcante'; Adriano Rodrigues Lima ${ }^{1}$; Cláudio Santos Teles Neto²; Ana Márjory Paiva Sousa;

Regislane Pinto Ribeiro5; Roberto Cláudio Fernandes Franco Pompeu ${ }^{1}$

\author{
${ }^{1}$ Embrapa Caprinos e Ovinos, Sobral, CE, Brasil \\ ${ }^{2}$ Centro Universitário Instituto Superior de Teologia Aplicada - UNINTA, Sobral, CE, Brasil \\ ${ }^{3}$ Universidade Estadual Vale do Acaraú - UVA, Campus da Betânia, Sobral, CE, Brasil \\ ${ }^{4}$ Embrapa Meio Norte, Teresina, PI, Brasil \\ ${ }^{5}$ Universidade Estadual do Ceará, Rede Nordeste de Biotecnologia - RENORBIO, Campus do Itaperi, Fortaleza, CE, Brasil
}

Received January 30, 2019

Accepted March 29, 2019

\begin{abstract}
The nematicidal effect of different organic materials was evaluated in order to develop a non-chemical alternative soil treatment for control of the free-living stages of small ruminant gastrointestinal nematodes. The selected organic materials were residues from the juice industry of acerola, cashew, grape, guava, papaya and pineapple, as well as castor residue from the biodiesel industry. LC90 results showed that pineapple residue was the most efficient inhibitor of larval development, followed by castor, grape, cashew, acerola, guava and papaya. Castor residue was also a good source of nitrogen and was used in a greenhouse experiment to prevent larval development in contaminated goat faeces that was deposited in pots containing the grasses Brachiaria brizantha (var. Paiaguás) or Megathyrsus maximus $x$ M. infestum (var. Massai). Castor residue caused a significant $(P<0.05)$ reduction $(85.04 \%)$ in Paiaguás grass contamination $\left(\right.$ L3.dry mass $\left.{ }^{-1}\right)$ and a reduction of $17.35 \%$ in Massai grass contamination $(\mathrm{P}>0.05)$, with an increase in the biomass production of Massai $(251.43 \%, \mathrm{P}<0.05)$ and Paiaguás $(109.19 \%, \mathrm{P}>0.05)$ grasses. This strategy, called Econemat ${ }^{\circledR}$, with good results in vitro shows to be promising on pasture increasing phytomass production.
\end{abstract}

Keywords: Gastrointestinal nematodes, Haemonchus contortus, organic residues, environmental control.

\section{Resumo}

O efeito nematicida de diferentes materiais orgânicos foi avaliado, com o objetivo de desenvolver um tratamento alternativo não químico do solo para o controle dos estágios de vida livre de nematoides gastrintestinais de pequenos ruminantes. Os materiais orgânicos selecionados foram resíduos da indústria de suco de acerola, caju, uva, goiaba, mamão e abacaxi, além do resíduo de mamona da indústria de biodiesel. Os resultados da LC90 mostraram que o resíduo de abacaxi foi o mais eficiente inibidor do desenvolvimento larval, seguido pela mamona, uva, caju, acerola, goiaba e mamáo. O resíduo de mamona também se mostrou uma boa fonte de nitrogênio, sendo usado em experimento em casa de vegetaçáo para prevenir o desenvolvimento larval em fezes contaminadas, depositadas em vasos, contendo as gramíneas Brachiaria brizantha (var. Paiaguás) ou Megathyrsus maximus x M. infestum (var. Massai). O resíduo de mamona reduziu $(85,04 \%)$ significativamente $(\mathrm{P}<0,05)$ a contaminação no capim-Paiaguás (L3.dry massa-1), 17,35\% no capim Massai $(\mathrm{P}>0,05)$, e aumentou a produção de biomassa das gramíneas Massai $(251,43 \%, \mathrm{P}<0,05)$ e Paiaguás $(109,19 \%, P>0,05)$. Essa estratégia, chamada Econemat ${ }^{\circledR}$, com bons resultados in vitro, mostra-se promissora nas pastagens aumentando a produção de fitomassa.

Palavras-chave: Nematoides gastrintestinais, Haemonchus contortus, resíduos orgânicos, controle ambiental. 


\section{Introduction}

Gastrointestinal nematodes (GIN) are potentially the most important cause of economic loss in the livestock industry when the stocking rate is high and the nutritional intake is limited (CRAIG, 2018). In tropical areas, where the temperature is favourable for larval development, GIN infection may be responsible for annual losses high than $25 \%$ of the herd (WALLER \& CHANDRAWATHANI, 2005). In addition, many populations of nematodes have become resistant to all existing anthelmintics, which is due, in part, to misuse of anthelmintics.

An alternative for controlling GIN infection is to devise schemes for integrated parasite management (IPM), which works by improving host resistance, using non-chemical means to control parasites, using chemicals judiciously, improving the monitoring of infection and resistance and developing a better understanding of the host-parasite relationship (SANGSTER, 2001).

By analysing the life cycle of GIN, it can be observed that the greatest number of GIN of small ruminants are in the free-living stages in the environment, the survival of infective larvae under tropical conditions lasts from 3-13 weeks, and temperature and moisture are the dominant influences on the epidemiology of the free-living stages of nematodes (reviewed by O'CONNOR et al., 2006).

Another point to consider is that the soil contains organic material, microorganisms (prokaryotes and eukaryotes), inorganic material and there are interactions between these components that can be favourable to increase one type over the other types. In plant science, the manipulation of these factors can be used to control the development of phytopathogenic agents. Two examples of this were reported by PiedraBuena et al. (2006) who used crop residues to control the plant nematode Meloidogyne incognita; and Raza et al. (2016) who used organic fertilizers to improve the antagonistic activity of biocontrol agents against the tomato wilt pathogen Ralstonia solanacearum. Additionally, Amaradasa et al. (2010) highlighted that soil characteristics, such as moisture, texture, biology, and composition, may play a role in survival of $H$. contortus infective larvae (L3) and their subsequent migration to vegetation. Therefore, why do not use this strategy to control the free-living stages of small ruminant nematodes and to break the parasite life cycle outside the animal?

Brazil is one of the largest castor oil and fruit producers in the world, with an output in 2016 of approximately 24.620 and 703.489 tons, respectively (FAO, 2016). These numbers indicate the generation of large quantities of agro-industrial residues that require correct management without the risk of polluting the environment.

To answer the question formulated above, this study tested the possibility of controlling the free-living stages of small ruminant GIN with a bionematicide from a botanical residue origin that could be directly applied to the soil. This strategy is called Econemat ${ }^{\circledR}$.

\section{Materials and Methods}

\section{Organic material}

The selected organic materials for this work were residues from the juice industry of acerola (Malpighia emarginata), cashew (Anacardium occidentale), grape (Vitis vinifera), guava
(Psidium guajava), papaya (Carica papaya) and pineapple (Ananas comosus), and castor (Ricinus communis) residue obtained from the biodiesel industry, as authorized by Brazilian government through of the Ministry of the Environment (register no. A76437E). All of these residues were sun-dried and crushed to obtain a flour. Grasses of Brachiaria brizantha var Paiaguás and Megathyrsus maximus $x$ $M$. infestum var. Massai were used in greenhouse experiments.

\section{Bromatological analysis of organic materials}

Samples were milled and analysed for dry matter (DM), ash, crude protein $(\mathrm{CP})$, and ether extract (EE). The analyses were performed in triplicate using the procedures described for the Association of Official Analytical Chemists (AOAC, 1990). Content of neutral detergent fibre (NDF) and acid detergent fibre (ADF) were determined according to Van Soest et al. (1991). The values were expressed as a percentage of dry matter ( $\%$ of DM).

\section{Larval Development Assay}

Faecal samples were collected directly from the rectum of donor goats naturally infected with GIN, and eggs were counted using the McMaster procedure (HANSEN \& PERRY, 1994). This protocol was approved by the Ethics Committee on the use of animals at the Embrapa Caprinos e Ovinos, under the number 03/2015. Data were expressed as the number of eggs per gram (EPG) of faeces. Faeces with 3000 EPG or more were used in the experiments. The larval development assay was done directly in faecal samples. One gram of contaminated faeces was transferred to a bottle and treated with $0.005 \mathrm{~g}, 0.01 \mathrm{~g}, 0.05 \mathrm{~g}, 0.1 \mathrm{~g}, 0.5 \mathrm{~g}$ or $1 \mathrm{~g}\left(\mathrm{w} . \mathrm{w}^{-1}\right)$ of each of the aforementioned flours. Water was added at a ratio of $2: 1[\mathrm{~mL}$ of water $=2$ ( $\mathrm{g}$ of faeces $+\mathrm{g}$ of flour of organic residue) , and the culture was incubated for $7 \mathrm{~d}$ at $27-28^{\circ} \mathrm{C}$. For some organic residues, it was necessary to test others concentrations between 0 and $1 \mathrm{~g}$. The control group contained $2 \mathrm{~mL}$ of water and $1 \mathrm{~g}$ of faeces. All controls and treatments were randomly allocated in the bottles in triplicate for each organic material concentration. Larvae were harvested at the end of the seventh day by rinsing the sides of each container with $10 \mathrm{~mL}$ of water. The total larvae were collected in a $15 \mathrm{~mL}$ tube and the suspension was adjusted to $2 \mathrm{~mL}$ after it has sedimented for two hours. The number of parasites per mL was estimated by counting 10 aliquots of $20 \mu \mathrm{L}$ (UENO \& GONÇALVES, 1998). From this result number of larvae. $\mathrm{g}^{-1}$ of faeces was calculated. The nematicidal efficiency (NE) was calculated by the following equation: $\mathrm{NE}=100-$ (number of larvae. $\mathrm{g}^{-1}$ of faeces in the treated samples $\mathrm{x}$ 100/number of larvae. $\mathrm{g}^{-1}$ of faeces in the control group). To distinguish the parasite genus, larvae were examined by optical microscopy.

\section{Lethal concentration 90 (LC90)}

The LC90 was determined in the larval development assay from the regression curve between the nematicidal efficiency parameter expressed in probits and the organic material concentrations

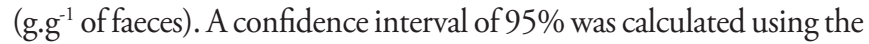
computer software IBM SPSS Statistics v. 21.0 (IBM Corp., 2012). 


\section{Nematicidal activity in soil}

Nematicidal activity was assayed in a greenhouse with controlled temperature $\left(30{ }^{\circ} \mathrm{C}\right)$ and moisture $(74 \%)$. Seeds of Brachiaria brizantha var Paiaguás and Megathyrsus maximus $x M$. infestum var. Massai were seeded in pots with a capacity of $5 \mathrm{~kg}$ of substrate. This substrate was previously autoclaved. Each pot received sixteen seeds distributed in four pits. Twenty pots were used per forage. After thirty days of seeding, the forages were cut at $30 \mathrm{~cm}$ from the soil, and the soil from all pots was uniformly contaminated with $50 \mathrm{~g}$ of faeces from two naturally infected goats containing a known number of eggs per gram of faeces $(3000<$ EPG $<7000)$. The faeces were recovered through the use of collection bags, kept intact and mixed before use. In $50 \%$ of the pots, $50 \mathrm{~g}$ of castor-cake flour was applied uniformly on the contaminated soil surface. Thereafter, the soil was irrigated with $100 \mathrm{~mL}$ of water in the control group (without castor-cake) and with $200 \mathrm{~mL}$ in the Econemat $^{\circledR}$ treated group (treated with castor-cake). Thirty days after the soil contamination the soil plant analysis development (SPAD) index was measured with the aid of a digital chlorophyll metre (Minolta SPAD 502). The readings were performed in the central third of the leaves in the ear base, in three plants of the useful area of the plot, in the morning. After this, the forages were collected with a cut near the soil. The infective larvae were recovered by the Baermann procedure (UENO \& GONÇALVES, $1998)$, then the forages were dried in a forced ventilation oven $\left(60{ }^{\circ} \mathrm{C}\right)$ to determine the dry mass.

\section{Statistical analysis}

In the larval development assay, the number of larvae. $\mathrm{g}^{-1}$ of faeces in treated groups with different concentrations of organic residue was compared directly to the control group using the Dunnett test using SPSS.

To evaluate nematicidal activity in the soil, the normality and homogeneity of the variables were first analysed by Shapiro-Wilk and Bartlett test. Next, the dry mass, number of infective larvae (L3) and number of infective larvae per dry mass (L3.dry mass ${ }^{-1}$ ) were transformed to logarithmic scale. Statistical comparison of the data was performed by $\mathrm{F}$ test, via analysis of variance. $P$ values less than 0.05 were considered significant.

\section{Results}

More than ninety percent of the larvae identified were of the species Haemonchus contortus. The in vitro faecal culture of eggs with organic residues showed a significant $(P<0.05)$ reduction in larval recovery with increasing concentrations of the residues (Figure 1). The pineapple and castor residues had lower LC90 scores, highlighting their efficacy in inhibiting growth (Table 1).

The amount of nitrogen required to obtain a maximum forage yield is high. The bromatological composition of the industrial residues showed that some residues are a good source of nitrogen (from crude protein) and can be good fertilizers, especially castor and papaya (Table 2). Castor residue showed good nematicidal activity in the larval development assay, and was selected for further testing in soil with grasses.
In soil tests, Econemat ${ }^{\circledR}$ led to a significant $(P<0.05)$ reduction $(85.04 \%)$ of Paiaguás grass contamination (L3.dry mass ${ }^{-1}$, Table 3 ). A difference between the grasses was also observed. The Massai grass showed low $(\mathrm{P}<0.05)$ contamination when its control group was compared with the Paiaguás control group (control, L3.dry mass $^{-1}$ variable, Table 3). Perhaps this resistance of Massai grass contributes to the efficiency of Econemat ${ }^{\circledR}$ to affect forage contamination, which was reduced by only $17.35 \%(\mathrm{P}>0.05)$. Importantly, Econemat ${ }^{\circledR}$ not only worked as a strategy to control environmental small ruminant GIN, but also could increase (251.43\%, P < 0.05) the biomass production of Massai (Dry mass, Table 3). The SPAD index reinforces these findings (SPAD index, Table 3), showing an increase in relative chlorophyll in the Massai Econemat ${ }^{\circledR}$ group, which can improve the quality of treated forage.
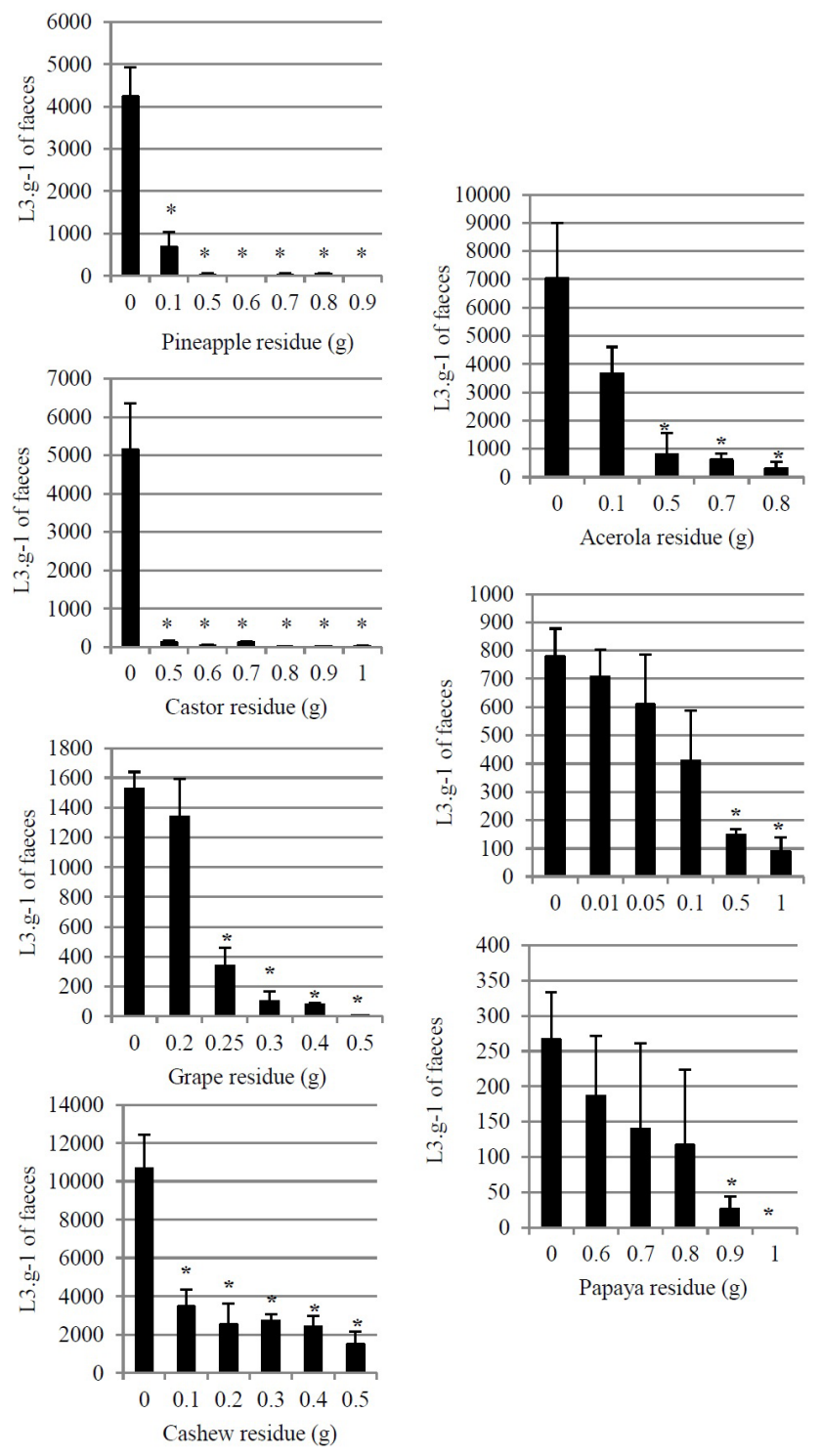

Figure 1. Number of infective larvae in faecal culture (L3. $\mathrm{g}^{-1}$ of faeces \pm Standard Error) seven days after treatment of $1 \mathrm{~g}$ of contaminated faeces with distinct concentrations of organic residues $\left(\mathrm{w} \cdot \mathrm{w}^{-1}\right) .\left({ }^{*}\right)$ significant difference $(P<0.05)$ between the control group and each concentration of residue used. 


\section{Discussion}

In the present work was explored the hypothesis that using a fertilizer with nematicidal activity it is possible to control GIN infection in small ruminants by breaking the parasite life cycle outside of the animal, namely, in the soil. This strategy is called Econemat ${ }^{\circledR}$.

The best results in vitro were obtained with pineapple and castor residues. A finding in the literature showed that aqueous extract of pineapple skin presented satisfactory dose-dependent inhibition in the egg hatch test and high efficacy in the larval development test on Haemonchus contortus (DOMINGUES et al., 2013). These findings suggest that ovicidal and larvicidal effects of pineapple residue may have contributed to its greater efficiency in vitro. Mashela \& Nthangeni (2002) observed that castor used in soil favoured the growth of tomato, without affecting soil $\mathrm{pH}$, and suppressed the nematode Meloidogyne incognita. In addition, ovicidal activity against Haemonchus contortus was already detected in fractions of the seed extracts of Ricinus communis by Salles et al. (2014). This present work shows that castor cake controls the

Table 1. Lethal concentration 90 (LC90) of organic residues for gastrointestinal nematodes of small ruminants in larval development assay, Probit analysis. The data are presented in increasing order of LC90.

\begin{tabular}{cc}
\hline $\begin{array}{c}\text { LC90 } \\
\text { (g of residue. } \mathbf{~}^{-1} \text { of faeces) }\end{array}$ & Organic residue \\
\hline 0.140 & Pineapple \\
0.244 & Castor \\
0.320 & Grape \\
0.348 & Cashew \\
0.551 & Acerola \\
0.808 & Guava \\
0.918 & Papaya \\
\hline
\end{tabular}

free-living stage of small ruminant nematodes in vitro and has the additional benefit of nourishing the plant. The latter activity has both direct and indirect implications for animal health.

Nitrogen fertilization represents a high cost in forage production, and the use of botanical residues as fertilizer can be a way to reduce production costs. According to Castro et al. (2016) experiments measuring the SPAD index demonstrated a higher nitrogen concentration in the leaf, indicating greater photosynthetic capacity and greater potential for the accumulation of sugar and nutrients in the plant tissue, in addition to promoting greater biomass. The application of castor residue provided a significant $(\mathrm{P}<0.05)$ increase in the SPAD index as well as in the dry matter of Massai grass. In Paiaguás grass, this increase was subtle. In Paiaguás grass the number of L3.dry mass $^{-1}$ was significantly reduced $(\mathrm{P}<0.05)$ in the Econemat ${ }^{\circledR}$-treated group, however subtle, in Massai grass. These findings reinforce that nitrogen is responsible for the increase of dry matter production and that there is a difference between grasses that affects larval survival. Carneiro \& Amarante (2008) and Amaradasa et al. (2010) have already reported this difference between grasses.

The success of grazing depends on different factors, and one of them is soil fertility, which directly influences dry matter production (SIMPSON et al., 2014). Dry matter production is correlated with the size of the root system area, the carbohydrate reserve and the number of leaves emitted. Gazda et al. (2009) observed that forages with a lower dry matter yield exhibited higher infestation by helminth larvae of sheep, and the animals presented increased averages of faecal egg count (FEC) compared to higher forage yield pastures. They also observed that lambs grazing on the pasture with a higher yield of dry matter showed decreasing FECs over time. These findings justify the use of fertilizer in the pasture, since it improves the chemical characteristics of the soil (VERESOGLOU et al., 2011; CONANT et al., 2017). In addition, microorganisms in soil can produce bioactive molecules (ZHUANG et al., 2013). The incorporation of organic matter in the soil can stimulate the proliferation of microorganisms,

Table 2. Centesimal and chemical composition of organic residues expressed as a percentage of dry matter (\% of DM).

\begin{tabular}{lccrrrrr}
\hline \multicolumn{1}{c}{ Variables } & Acerola & Cashew & Grape & Guava & Papaya & Pineapple & Castor \\
\hline Dry matter content (\%) & 87.33 & 90.61 & 89.52 & 90.65 & 81.69 & 81.36 & 93.55 \\
Crude protein (\% of DM) & 10.13 & 14.11 & 11.11 & 9.69 & 23.89 & 6.65 & 29.91 \\
Mineral matter (\% of DM) & 6.09 & 7.19 & 7.47 & 5.88 & 2.69 & 5.01 & 5.02 \\
Ethereal extract (\% of DM) & 3.72 & 5.30 & 11.81 & 13.22 & 6.41 & 1.57 & 9.48 \\
Neutral detergent fibre (\% of DM) & 60.45 & 62.38 & 53.09 & 69.69 & 27.84 & 45.56 & 53.55 \\
Acid detergent fibre (\% of DM) & 36.84 & 55.23 & 37.26 & 40.74 & 23.79 & 20.06 & 38.64 \\
\hline
\end{tabular}

Table 3. Number of infective larvae per unit dry mass (L3.dry mass ${ }^{-1}$ ), number of infective larvae (L3), dry mass (g) and SPAD index in Brachiaria brizantha var. Paiaguás and Megathyrsus maximus x $M$. infestum var. Massai cultured in a greenhouse, in soil contaminated with faeces $(50 \mathrm{~g})$ containing eggs of gastrointestinal nematode only (control) or with contaminated faeces $(50 \mathrm{~g})$ and treated (50 g) with castor cake $\left(\right.$ Econemat $\left.^{\circledR}\right)$.

\begin{tabular}{lccccc}
\hline \multicolumn{1}{c}{ Grasses } & Treatments & L3.Dry mass ${ }^{-1}$ & L3 & Dry mass $(\mathbf{g})$ & SPAD index \\
\hline Brachiaria brizantha var. & Control & $376.39 \mathrm{a}^{*}$ & $7114.61 \mathrm{a}$ & $19.59 \mathrm{a}$ & $27.51 \mathrm{a}$ \\
Paiaguás & Econemat $^{\circledR}$ & $56.32 \mathrm{~b}$ & $1137.03 \mathrm{~b}$ & $21.39 \mathrm{a}$ & $27.67 \mathrm{a}$ \\
Megathyrsus maximus $x$ & Control & $52.15 \mathrm{a}^{*}$ & $802.11 \mathrm{a}$ & $15.38 \mathrm{a}$ & $18.97 \mathrm{a}$ \\
M. infestum var. Massai & Econemat $^{\circledR}$ & $43.10 \mathrm{a}$ & $1667.08 \mathrm{a}$ & $38.67 \mathrm{~b}$ & $23.77 \mathrm{~b}$ \\
\hline
\end{tabular}

${ }^{a, b}$ Letters in columns between the treatments of the same grass indicate statistically significant differences $(\mathrm{P}<0.05) . *$ Statistically significant difference $(\mathrm{P}<0.05)$ between the control groups of the two grasses. 
resulting in increases in its activity and in the accumulation of compounds that act as nematicides.

Low forage supplies or high stockings predispose animals to a greater ingestion of infective larvae of gastrointestinal helminths, and consequently may present a more intense parasitic infection (GAZDA et al., 2009). The use of Econemat ${ }^{\circledR}$ in IPM is reinforced since it can contribute on two fronts: as a fertilizer and a potencial nematicide. In this way, Econemat ${ }^{\circledR}$ can be considered as a sustainable control strategy to be added to IPM. Its use would serve to reduce the use of anthelmintics, to make possible the production of small ruminants in irrigated pastures and to contribute to the development of the organic production of small ruminants. This is a first work, but in the future, many nematicide fertilizers can be evaluated and identified for use in the most distinct small ruminant producing regions.

\section{Acknowledgements}

This work was supported by EMBRAPA (Empresa Brasileira de Pesquisa Agropecuária, grand number 03.13.10.006.00.00) and fellowships from CAPES (Coordination for the Improvement of Higher Education Personnel), CNPq (National Council for Scientific and Technological Development) and FUNCAP (Ceará Research Foundation). We thank Felipe Cavalcante Machado, Lidiane Viana Ximenes, Helena Araújo da Ponte and José Lourival Balbino for assistance in the field and laboratory.

\section{References}

Amaradasa BS, Lane RA, Manage A. Vertical migration of Haemonchus contortus infective larvae on Cynodon dactylon and Paspalum notatum pastures in response to climatic conditions. Vet Parasitol 2010; 170(1-2): 78-87. http://dx.doi.org/10.1016/j.vetpar.2010.01.026. PMid:20149541.

Carneiro RD, Amarante AFT. Seasonal effect of three pasture plants species on the free-living stages of Haemonchus contortus. Arq Bras Med Vet Zootec 2008; 60(4): 864-872. http://dx.doi.org/10.1590/S010209352008000400014 .

Castro CS, Lobo UGM, Rodrigues LM, Backes C, Santos AJM. Efficiency of organic fertilizer use for tropical forages. Rev Agric Neotrop 2016; 3(4): 48-54. http://dx.doi.org/10.32404/rean.v3i4.1144.

Conant RT, Cerri CEP, Osborne BB, Paustian K. Grassland management impacts on soil carbon stocks: a new synthesis. Ecol Appl 2017; 27(2): 662-668. http://dx.doi.org/10.1002/eap.1473. PMid:27875004.

Craig TM. Gastrointestinal nematodes, diagnosis and control. Vet Clin North Am Food Anim Pract 2018; 34(1): 185-199. http://dx.doi. org/10.1016/j.cvfa.2017.10.008. PMid:29421029.

Domingues LF, Giglioti R, Feitosa KA, Fantatto RR, Rabelo MD, Sena Oliveira MC, et al. In vitro and in vivo evaluation of the activity of pineapple (Ananas comosus) on Haemonchus contortus in Santa Inês sheep. Vet Parasitol2013; 197(1-2): 263-270. http://dx.doi.org/10.1016/j. vetpar.2013.04.031. PMid:23688638.

Food and Agriculture Organization of United Nations - FAO. FAOSTAT: FAO's corporate database [online]. Rome: FAO; 2016 [cited 2018 Sep]. Available from: http://www.fao.org/faostat/en/\#data/QC

Gazda TL, Piazzetta RG, Dittrich JR, Monteiro ALG, Thomaz-Soccol V. Distribution of nematode larvae of sheep in tropical pasture plants.
Small Rumin Res 2009; 82(2-3): 94-98. http://dx.doi.org/10.1016/j. smallrumres.2009.02.004.

Hansen J, Perry B. The epidemiology, diagnosis, and control of helminth parasites of ruminants. 4th ed. Nairobi: International Laboratory for Research on Animal Diseases; 1994. 74p.

IBM Corp. Released 2012. IBM SPSS Statistics for Windows, Version 21.0. Armonk: IBM Corp.; 2012.

Mashela PW, Nthangeni ME. Efficacy of Ricinus communis fruit meal with and without Bacillus species on suppression of Meloidogyne incognita and growth of tomato. J Phytopathol 2002; 150(7): 399-402. http://dx.doi. org/10.1046/j.1439-0434.2002.00770.x.

O'Connor LJ, Walkden-Brown SW, Kahn LP. Ecology of the freeliving stages of major trichostrongylid parasites of sheep. Vet Parasitol 2006; 142(1-2): 1-15. http://dx.doi.org/10.1016/j.vetpar.2006.08.035. PMid:17011129.

Official Methods of Analysis - AOAC. Association of official analytical chemists. 15. ed. Arlington: AOAC; 1990.

Piedrabuena A, García-Alvarez A, Díez-Rojo MA, Bello A. Use of crop residues for the control of Meloidogyne incognita under laboratory conditions. Pest Manag Sci 2006; 62(10): 919-926. http://dx.doi. org/10.1002/ps.1257. PMid:16927410.

Raza W, Wei Z, Ling N, Huang Q, Shen Q. Effect of organic fertilizers prepared from organic waste materials on the production of antibacterial volatile organic compounds by two biocontrol Bacillus amyloliquefaciens strains. J Biotechnol 2016; 227: 43-53. http://dx.doi.org/10.1016/j. jbiotec.2016.04.014. PMid:27067079.

Salles HO, Braga ACL, Nascimento MTSC, Sousa AMP, Lima AR, Vieira LS, et al. Lectin, hemolysin and protease inhibitors in seed fractions with ovicidal activity against Haemonchus contortus. Rev Bras Parasitol Vet 2014; 23(2): 136-143. http://dx.doi.org/10.1590/S1984-29612014050. PMid:25054490.

Sangster NC. Managing parasiticide resistance. Vet Parasitol 2001; 98(1-3): 89-109. http://dx.doi.org/10.1016/S0304-4017(01)00425-3. PMid:11516581.

Simpson RJ, Richardson AE, Nichols SN, Crush JR. Pasture plants and soil fertility management to improve the efficiency of phosphorus fertiliser use in temperate grassland systems. Crop Pasture Sci 2014; 65(6): 556-575. http://dx.doi.org/10.1071/CP13395.

Ueno H, Gonçalves PC. Manual para diagnóstico das helmintoses de ruminantes. Tokyo: Japan International Cooperation Agency; 1998.

Van Soest PJ, Robertson JB, Lewis BA. Methods for dietary fiber, neutral detergent fiber, and nonstarch polyssacarides in relation to animal nutrition. J Dairy Sci 1991; 74(10): 3583-3597. http://dx.doi.org/10.3168/jds. S0022-0302(91)78551-2. PMid:1660498.

Veresoglou SD, Voulgari OK, Sen R, Mamolos AP, Veresoglou SD. Effects of nitrogen and phosphorus fertilization on soil $\mathrm{pH}$-plant productivity relationships in upland grasslands of Northern Greece. Pedosphere 2011; 21(6): 750-752. http://dx.doi.org/10.1016/S1002-0160(11)60178-1.

Waller PJ, Chandrawathani P. Haemonchus contortus: Parasite problem No. 1 from Tropics - Polar Circle: Problems and prospects for control based on epidemiology. Trop Biomed 2005; 22(2): 131-137. PMid:16883278.

Zhuang X, Gao J, Ma A, Fu S, Zhuang G. Bioactive molecules in soil ecosystems: masters of the underground. Int J Mol Sci 2013; 14(5): 8841-8868. http://dx.doi.org/10.3390/ijms14058841. PMid:23615474. 